\title{
Spatiotemporal patterns of tundra fires: late-Quaternary charcoal records from Alaska
}

\author{
M. L. Chipman ${ }^{1}$, V. Hudspith ${ }^{2, a}$, P. E. Higuera ${ }^{3}$, P. A. Duffy ${ }^{4}$, R. Kelly ${ }^{2, b}$, W. W. Oswald ${ }^{5}$, and F. S. Hu ${ }^{1,2,6}$ \\ ${ }^{1}$ Program in Ecology, Evolution, and Conservation Biology, University of Illinois, 505 S. Goodwin Ave., Urbana, \\ Illinois 61802, USA \\ ${ }^{2}$ Department of Plant Biology, University of Illinois, 505 S. Goodwin Ave., Urbana, Illinois 61802, USA \\ ${ }^{3}$ College of Natural Resources, University of Idaho, P.O. Box 441133, Moscow, Idaho 83844, USA \\ ${ }^{4}$ Neptune and Company, Inc., 1435 Garrison Street, Suite 110, Lakewood, Colorado 80215, USA \\ ${ }^{5}$ Institute for Liberal Arts and Interdisciplinary Studies, Emerson College, 120 Boylston St., Boston, Massachusetts 02116, \\ USA \\ ${ }^{6}$ Department of Geology, University of Illinois, 605 E. Springfield Ave., Champaign, Illinois 61820, USA \\ ${ }^{a}$ now at: Department of Geography, University of Exeter, Laver Building 440, Exeter, EX4 4QE, UK \\ ${ }^{b}$ now at: Nicholas School of the Environment, Duke University, Box 90338, Durham, North Carolina 27708, USA
}

Correspondence to: F. S. Hu (fshu@life.illinois.edu)

Received: 21 November 2014 - Published in Biogeosciences Discuss.: 12 February 2015

Revised: 08 June 2015 - Accepted: 11 June 2015 - Published: 03 July 2015

\begin{abstract}
Anthropogenic climate change has altered many ecosystem processes in the Arctic tundra and may have resulted in unprecedented fire activity. Evaluating the significance of recent fires requires knowledge from the paleofire record because observational data in the Arctic span only several decades, much shorter than the natural fire rotation in Arctic tundra regions. Here we report results of charcoal analysis on lake sediments from four Alaskan lakes to infer the broad spatial and temporal patterns of tundra-fire occurrence over the past 35000 years. Background charcoal accumulation rates are low in all records (range is 0 0.05 pieces $\mathrm{cm}^{-2} \mathrm{yr}^{-1}$ ), suggesting minimal biomass burning across our study areas. Charcoal peak analysis reveals that the mean fire-return interval (FRI; years between consecutive fire events) ranged from ca. 1650 to 6050 years at our sites, and that the most recent fire events occurred from ca. 880 to 7030 years ago, except for the CE 2007 Anaktuvuk River Fire. These mean FRI estimates are longer than the fire rotation periods estimated for the past 63 years in the areas surrounding three of the four study lakes. This result suggests that the frequency of tundra burning was higher over the recent past compared to the late Quaternary in some tundra regions. However, the ranges of FRI estimates from our paleofire records overlap with the expected values based
\end{abstract}

on fire-rotation-period estimates from the observational fire data, and the differences are statistically insignificant. Together with previous tundra-fire reconstructions, these data suggest that the rate of tundra burning was spatially variable and that fires were extremely rare in our study areas throughout the late Quaternary. Given the rarity of tundra burning over multiple millennia in our study areas and the pronounced effects of fire on tundra ecosystem processes such as carbon cycling, dramatic tundra ecosystem changes are expected if anthropogenic climate change leads to more frequent tundra fires.

\section{Introduction}

The tundra biome occupies some of the coldest regions on Earth and is thus characterized by low biomass compared to other ecosystems. Despite low productivity in tundra ecosystems, circumpolar Arctic regions account for approximately $50 \%$ of all belowground soil organic carbon (Schuur et al., 2008; Grosse et al., 2011), in part because low decomposition rates and infrequent burning allow for carbon accumulation over millennia. In Alaska, observational records show that fire has been rare in the majority of tundra ecoregions dur- 
ing the past 60 years (Rocha et al., 2012). However, anthropogenic climate change may have increased the rate of tundra burning. For example, in Common Era (CE) 2007, the Anaktuvuk River Fire (ARF) burned approximately $1000 \mathrm{~km}^{2}$, doubling the total area burned on the Alaskan North Slope since CE 1950 (Jones et al., 2009; Mack et al., 2011). The Noatak River Watershed, a tundra region in northwestern Alaska that has historically burned more frequently than the North Slope, also experienced an increase in area burned over the past several decades (Rocha et al., 2012) and a record high number of fires in CE 2010 (AICC, 1943-2013). With anticipated acceleration of anthropogenic climate change in the Arctic, fires may become increasingly important in tundra regions that rarely burn at present.

Tundra fires can dramatically impact a variety of ecosystem processes. For example, the ARF released an amount of carbon comparable to the net carbon sink of the entire Arctic tundra biome in a typical year in the latter part of the 20th century (Mack et al., 2011). Decreased organic soil thickness and moss cover following the fire resulted in changes to the ground thermal regime, including increased permafrost thaw depth and higher soil temperatures (Rocha and Shaver, 2011). Enhanced microbial activity and access to deeper soil layers associated with permafrost thaw can further increase the release of tundra-soil carbon to the atmosphere over decadal timescales. Thus increased tundra burning in response to anthropogenic climate change may lead to pronounced ecosystem changes.

The brevity of the observational fire record makes it difficult to characterize the variability and drivers of tundra-fire regimes. Therefore, fire-history reconstructions from lakesediment charcoal analysis provide key information on the long-term dynamics of tundra burning and a necessary context to assess recent changes. For example, paleofire data reveal that the area within the ARF had not experienced fire in at least 5000 years (Hu et al., 2010). In contrast, paleorecords from the Noatak River Watershed suggest frequent tundra burning over the past 2000 years, with mean fire-return intervals (FRI; the time interval between consecutive fires) comparable to those in modern-day boreal forests (ca. 100 300 years; Higuera et al., 2011). Paleorecords also reveal vegetation-mediated responses of tundra-fire regimes to climate change, such as an increase in fire frequency in northcentral Alaska in association with the expansion of shrubs in the tundra vegetation of the last glacial/interglacial transition (Higuera et al., 2009). However, existing paleorecords of tundra burning are restricted to a few sites (Fig. 1), and we know little about the patterns and drivers of tundra burning elsewhere. To address this limitation, and to place modern fire regimes in a broader context of past variability, we conducted charcoal analysis of sediment cores from four lakes in Alaska. The results allow us to examine the spatiotemporal patterns of fire regimes over the late Quaternary and provide a context of natural fire-regime variability for assessing recent tundra burning.

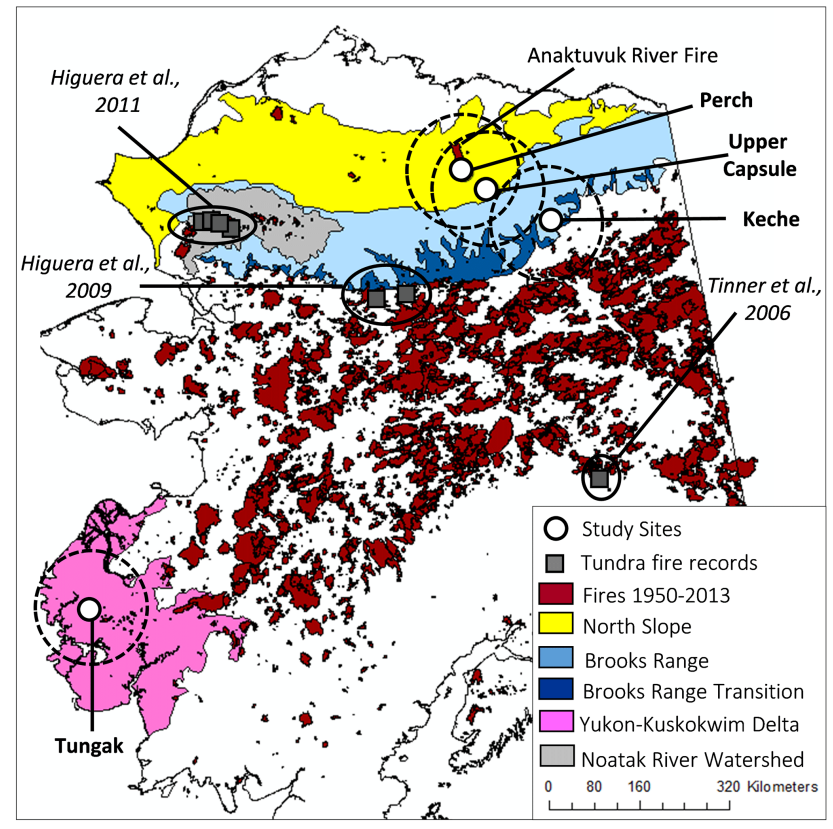

Figure 1. Map of tundra ecoregions (modified after Nowacki et al., 2001) with study sites (shown with $100 \mathrm{~km}$ buffers) and locations of previous tundra-fire-history reconstructions. CE 1950-2013 fire perimeters are from http://fire.ak.blm.gov.

\section{Study sites}

Our four study sites are located in three tundra ecoregions of Alaska that are characterized by a paucity of fires in the observational record and that span a range of climate conditions and tundra-vegetation types. Ecoregion classification and descriptions follow Nowacki et al. (2001), modified to delineate the Brooks Range Transition zone between boreal and tundra vegetation as a distinct ecoregion (Fig. 1). For modern climate near each site, June-August (JJA) average temperature and total precipitation were estimated within a $5 \mathrm{~km}$ radius around each lake (Table 1), using data from the Parameter-elevation Regression on Independent Slopes Model (PRISM Climate Group, 2012) spanning 1971-2000 (data downloaded from SNAP, 2014).

Perch Lake $\left(68.94^{\circ} \mathrm{N}, 150.50^{\circ} \mathrm{W}\right)$ and Upper Capsule Lake $\left(68.63^{\circ} \mathrm{N}, 149.41^{\circ} \mathrm{W}\right)$ are small kettle basins located in the Brooks Range Foothills ecoregion (hereafter referred to as the North Slope; Fig. 1), which is characterized by gently rolling hills, narrow alluvial valleys, and surficial deposits comprised primarily of glacial moraines, outwash, and alluvial materials. Mean JJA temperature in this area is $10.5 \pm 0.4{ }^{\circ} \mathrm{C}$, and total JJA precipitation is $144 \pm 44 \mathrm{~mm}$ (1971-2000 mean and standard deviation; Table 1). Soils in the region feature continuous permafrost overlain by organicrich horizons. Vegetation is dominated by mixed shrub-sedge tussock tundra, interspersed with willow thickets along rivers and small drainages. Perch Lake lies within the Anaktuvuk 
Table 1. Lake characteristics for the four study sites. June-August (JJA) climatology is from PRISM-derived data spanning 1971-2000, summarized over an approximate radius of $5 \mathrm{~km}$ around each lake (representing 20-21 PRISM pixels). Circumpolar Arctic Vegetation Map (CAVM) landcover classification is based on Walker et al. (2005). "Boreal transition" indicates that the site is outside of the CAVM classification.

\begin{tabular}{|c|c|c|c|c|}
\hline \multirow[b]{2}{*}{ Characteristic } & \multicolumn{4}{|c|}{ Site } \\
\hline & Perch & Upper Capsule & Keche & Tungak \\
\hline \multicolumn{5}{|l|}{ Site } \\
\hline Latitude & $68^{\circ} 56^{\prime} 29.4^{\prime \prime} \mathrm{N}$ & $68^{\circ} 37^{\prime} 43.0^{\prime \prime} \mathrm{N}$ & $68^{\circ} 1^{\prime} 2.8^{\prime \prime} \mathrm{N}$ & $61^{\circ} 25^{\prime} 37.9^{\prime \prime} \mathrm{N}$ \\
\hline Longitude & $150^{\circ} 29^{\prime} 57.7^{\prime \prime} \mathrm{W}$ & $149^{\circ} 24^{\prime} 48.7^{\prime \prime} \mathrm{W}$ & $146^{\circ} 55^{\prime} 25.7^{\prime \prime} \mathrm{W}$ & $164^{\circ} 12^{\prime} 2.2^{\prime \prime} \mathrm{W}$ \\
\hline Elevation (m a.s.1.) & 400 & 800 & 740 & 25 \\
\hline Surface area (ha) & 14.0 & 1.1 & 80.2 & 117.0 \\
\hline Max. water depth (m) & 12.6 & 5.7 & 15 & 15.4 \\
\hline Coring water depth (m) & 12.6 & 5.7 & 14.5 & 14.8 \\
\hline CAVM landcover class & Tussock-sedge, dwarf-shrub tundra & Tussock-sedge, dwarf-shrub tundra & Boreal transition (near treeline) & Low-shrub tundra \\
\hline JJA temperature $\left({ }^{\circ} \mathrm{C}\right)$ & $10.9 \pm 0.04$ & $10.0 \pm 0.1$ & $10.8 \pm 0.5$ & $12.3 \pm 0.1$ \\
\hline JJA total precip. (mm) & $101 \pm 5$ & $187 \pm 7$ & $142 \pm 14$ & $169 \pm 2$ \\
\hline \multicolumn{5}{|l|}{ Record } \\
\hline Core length $(\mathrm{cm})$ & 209.5 & 329 & 321 & 353.5 \\
\hline Coring year (cal yr BP) & -58 & -47 & -57 & -62 \\
\hline Basal age (cal yr BP) & 9460 & 12100 & 11480 & 35430 \\
\hline Sed. rate $\left(\mathrm{cm} \mathrm{yr}^{-1}\right)$ & $0.045 \pm 0.080$ & $0.031 \pm 0.011$ & $0.030 \pm 0.027$ & $0.030 \pm 0.039$ \\
\hline
\end{tabular}

River Fire (ARF), and Upper Capsule Lake is approximately $50 \mathrm{~km}$ to the southeast of Perch Lake and $40 \mathrm{~km}$ from the southernmost portion of the ARF (Fig. 1).

Keche Lake $\left(68.02^{\circ} \mathrm{N}, 146.92^{\circ} \mathrm{W}\right)$ lies in the southeastern portion of the Brooks Range ecoregion. Sedimentary and metamorphic deposits dominate this steep mountainous terrain. Mean JJA temperature and total JJA precipitation in the area are $10.8 \pm 0.5^{\circ} \mathrm{C}$ and $142 \pm 14 \mathrm{~mm}$, respectively. The modern vegetation around Keche Lake is forest tundra, in the transition zone between tundra and boreal forest, as defined by the Circumpolar Arctic Vegetation Map (CAVM Team, 2003; Walker et al., 2005). The area is designated as the Brooks Range Transition (Fig. 1), and the lake is approximately $200 \mathrm{~m}$ below treeline with stands of Picea glauca (white spruce) in the watershed. The early-Holocene vegetation in this area was shrub tundra, based on the regional pollen data set (Anderson and Brubaker, 1994).

Tungak Lake $\left(61.43^{\circ} \mathrm{N}, 164.20^{\circ} \mathrm{W}\right)$ is located in the broad Yukon-Kuskokwim Delta ecoregion of southwestern Alaska. Mean JJA temperature and total JJA precipitation in the Tungak Lake area are $12.3 \pm 0.1{ }^{\circ} \mathrm{C}$ and $169 \pm 2 \mathrm{~mm}$, respectively. The regional landscape is characterized by shallow organic soils, discontinuous permafrost, and abundant thermokarst lakes. Tungak Lake is located in an isolated area of low-shrub tundra surrounded by low-shrub wetlands.

\section{Material and methods}

Two overlapping sediment cores were obtained from the deepest portion of Keche and Tungak lakes in the summers of 2007 and 2012, respectively. Perch Lake was first cored in 2008, and charcoal analysis on the core was conducted to infer fire history of the past 5000 years (Hu et al., 2010).
For this study, we include additional data from deeper sediments obtained in 2011, extending the fire record to the past ca. 9500 years. The sediment cores from Upper Capsule Lake were obtained in 1997 for pollen analysis (Oswald et al., 2003). At each lake, a polycarbonate tube fitted with a piston was used to retrieve an intact sediment-water interface and the uppermost sediments, and a modified Livingstone piston corer (Wright et al., 1984) was used to obtain deeper sediments. The top $5-20 \mathrm{~cm}$ of unconsolidated surface sediments was extruded at $0.5 \mathrm{~cm}$ resolution in the field, and the remaining sections were split lengthwise in the laboratory. Overlapping cores were correlated based on visible stratigraphic transitions and magnetic susceptibility.

Chronologies are based on ${ }^{210} \mathrm{~Pb}$ analysis on bulk sediments (except at Upper Capsule Lake, where no ${ }^{210} \mathrm{~Pb}$ analysis was performed) and AMS ${ }^{14} \mathrm{C}$ analysis on terrestrial macrofossils (Fig. 2; Supplement Table S1). Preparation of ${ }^{210} \mathrm{~Pb}$ samples followed Eakins and Morrison (1978), and activity was measured with an Ortec Octête Plus alpha spectrometer at the University of Illinois. We used a constantrate-of-supply (CRS) model adapted from Binford (1990) to estimate ${ }^{210} \mathrm{~Pb}$-based sample ages. For ${ }^{14} \mathrm{C}$ measurements, terrestrial macrofossils were treated with an acidbase-acid procedure (Oswald et al., 2005) and submitted to Lawrence Livermore National Laboratory (Livermore, CA) or INSTAAR radiocarbon laboratory (Boulder, $\mathrm{CO})$. All ${ }^{14} \mathrm{C}$ ages were calibrated to years before CE 1950 (cal BP; calibrated years before CE 1950) using the IntCal 09 data set in CALIB v6.1.0 (Stuiver and Reimer, 1993; Reimer et al., 2009). A thick layer of tephra was visible in the sediments of Tungak Lake spanning $5-38 \mathrm{~cm}$. We assume that this tephra was deposited during the Aniakchak eruption, which was widespread in the region with a well-constrained age of 

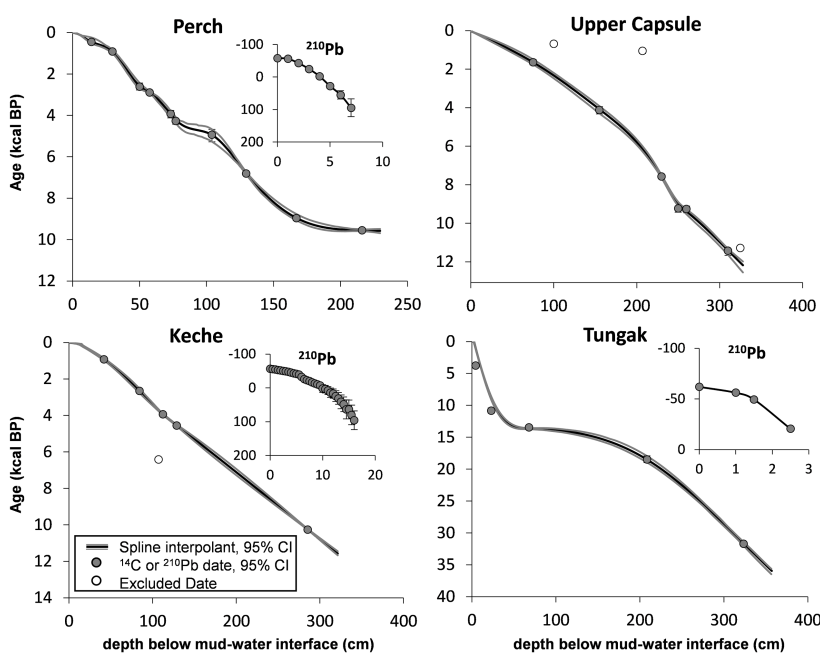

Figure 2. Age-depth relationships for all sites, modeled with a cubic spline and presented with $95 \%$ confidence intervals.

$3.7 \pm 0.2$ kcal BP (Begét et al., 1992; Kaufman et al., 2012). We adjusted the depth of the sediment core by assuming that the tephra deposited instantaneously. Age models were developed by fitting a weighted cubic smoothing spline through all ages, and confidence intervals were estimated with bootstrap resampling using the MCAgeDepth program (2009) (Higuera et al., 2009).

For charcoal analysis, $0.5-2.0 \mathrm{~cm}^{3}$ subsamples were taken from continuous $0.25-1.0 \mathrm{~cm}$ core slices. Sediments were freeze-dried overnight, immersed in $5 \mathrm{~mL}$ of bleach and $5 \mathrm{~mL}$ of $10 \%$ sodium metaphosphate for approximately $20 \mathrm{~h}$, and then washed through a $125 \mu \mathrm{m}$ sieve. Charcoal particles $>125 \mu \mathrm{m}$ were enumerated under a dissecting microscope (10-40× magnification). Because charcoal counts are low at all of our sites, count data from adjacent samples were aggregated to obtain a final sampling resolution of $0.5-1.0 \mathrm{~cm}$ and volume of $2-4 \mathrm{~cm}^{3}$. Charcoal concentrations (pieces $\mathrm{cm}^{-3}$ ) were multiplied by the sediment accumulation rate $\left(\mathrm{cm} \mathrm{yr}^{-1}\right)$ to calculate charcoal accumulation rates (CHAR, pieces $\mathrm{cm}^{-2} \mathrm{yr}^{-1}$ ).

Although tundra fires consume lower biomass than fires in forest ecosystems, previous studies have shown that charcoal production is sufficient for reliable detection of local fires in lake-sediment records (Hu et al., 2010; Higuera et al., 2011). We infer local fires (within 500-1000 m of each lake; Higuera et al., 2007, 2011) from our CHAR records using the CharAnalysis v1.1 program (2013), modified as described below. Prior to statistical analyses, charcoal samples were interpolated to the median sample resolution of each record (Table 2) to account for unequal sampling from variable sediment accumulation rates. Low and zero charcoal counts were prevalent in all records. To guard against interpretation of fluctuations based on small differences between samples, we used a wide time window to estimate the low- frequency component and limit our interpretation of "background" CHAR to broad trends in the data. Background trends in each interpolated CHAR record were estimated using a Lowess smoother (Cleveland, 1979) with a 3000-year time window. A detrended series was created by subtracting this low-frequency trend from the interpolated CHAR series. The method commonly used for establishing the threshold for charcoal peak detection is based on the assumption that the noise component is normally distributed around the background trend (Higuera et al., 2010). However, this assumption is poorly met in our records because of the prevalence of CHAR values of exactly zero. Thus, we used a zeroinflated gamma (ZIG) distribution to separate the detrended series into "noise" and "peak" components, specifying the 99th percentile of the distribution as the global threshold for each record. The noise component is assumed to reflect random variability, such as charcoal deposition from distant fires and/or local depositional processes, and the peak component is used to identify fire events within the interpolated sample (e.g., Gavin et al., 2003; Lynch et al., 2004; Higuera et al., 2007).

We used a minimum count screening to remove peak identification that could arise from statistical noise associated with low charcoal particle counts (Gavin et al., 2006). If the charcoal count for a peak sample had a $>15 \%$ probability of being drawn from the same Poisson distribution as the lowest non-peak count within the previous 1500 years, the peak was rejected. After thresholds were determined, we calculated a signal-to-noise index (SNI) to evaluate the suitability of our records for peak detection (Kelly et al., 2011). The identified charcoal peaks were interpreted as fire events, and fire-return intervals (FRIs) were calculated as years between individual fire events.

To place our fire-history reconstructions in the context of fires on the modern landscape, we calculated the fire-rotation period (FRP, also termed fire cycle; Johnson and Gutsell, 1994) for each site. The FRP value calculated from spatially explicit data of fire observations is equivalent to the mean FRI calculated from temporal variations in fire occurrence for any point on the landscape (Johnson and Gutsell, 1994), and thus modern FRP can be compared to paleo-inferred mean FRI (Kelly et al., 2013). We defined the FRP at each lake as $t /\left(\sum_{i=1}^{n} a_{i} / A\right)$, where $t$ is the temporal span of the historical fire record (CE 1950-2013, 63 years), $a_{i}$ is the area $\left(\mathrm{km}^{2}\right)$ burned by fire $i, n$ is the total number of fires (with a range of 2 to 19$)$, and $A$ is the vegetated area $\left(\mathrm{km}^{2}\right)$ within the $100 \mathrm{~km}$ buffer (Baker, 2009). We found that site-specific FRP calculations were generally stable for radii between 60 and $140 \mathrm{~km}$, suggesting the $100 \mathrm{~km}$ radius is an appropriate area to characterize the modern fire regime. To obtain the vegetated area within each buffer, we subtracted barren and open water landcover classes (defined by the National Landcover Database vegetation survey from 2006 (NLDC, 2006) and the North American Land Change Monitoring System; NALCMS, 2005) from the total area, based on the rationale 
Table 2. Results of charcoal analysis and modern fire rotation period (FRP) from all study sites. Fire-return intervals (FRIs) for each site are given as the range, mean, and most recent FRI (")" indicates that there is no modern or previous fire in the record to constrain the interval). Modern FRPs are calculated for the vegetated areas within a $100 \mathrm{~km}$ radius around each lake, with human-caused fires excluded from analysis. For each FRP, a $95 \%$ quantile range of expected FRIs is calculated, assuming an exponential distribution with the mean equal to the FRP.

\begin{tabular}{lllll}
\hline & \multicolumn{3}{c}{ Site } \\
\cline { 2 - 5 } & Perch & Upper Capsule & Keche & Tungak \\
\hline Charcoal Analysis & & & \\
Mean sample resolution (yr sample ${ }^{-1}$ ) & $22.7 \pm 13.1$ & $37.1 \pm 14.1$ & $9.3 \pm 1.4$ & $50.3 \pm 49.4$ \\
Average (range) charcoal count (pieces) & $2.1(0-114)$ & $0.5(0-11)$ & $0.7(0-85)$ & $0.7(0-25)$ \\
Average (range) charcoal conc. (pieces cm ${ }^{-3}$ ) & $0.56(0-28.5)$ & $0.14(0-2.75)$ & $0.29(0-34.0)$ & $0.19(0-6.25)$ \\
Interpolation interval (yr) & 43 & 65 & 18 & 89 \\
Number of peaks identified as fires & 3 & 1 & 6 & 5 \\
Range of FRIs (yr) & $2924-6536$ & $>5590$ to $>6500$ & $144-3906$ & 1157 to $>9968$ \\
Mean FRI (yr) & 4730 & 6045 & 1648 & 5904 \\
Most recent FRI (yr) & 6536 & $>6500$ & $>882$ & $>7031$ \\
\hline Modern Fire Rotation Period (FRP) & & & 21666 & 13814 \\
Burnable area within 100 km radius (km $\left.{ }^{2}\right)$ & 27809 & 21976 & 19 & 12 \\
Number of observed fires 1950-2013 & 3 & 2 & 1798.5 & 116.9 \\
Total area burned 1950-2013 (km $\left.{ }^{2}\right)$ & 932.1 & 679.4 & 771 & 7560 \\
FRP (yr) & 1909 & 2070 & $19-2844$ & $191-27888$ \\
95\% quantile range of expected FRIs (yr) & $48-7042$ & $52-7636$ & & \\
\hline
\end{tabular}

that these cover types do not have burnable fuels. We also removed any fire perimeters that were described as humancaused. We present each FRP with the $95 \%$ quantile range from an exponential distribution with mean equal to the FRP. These bounds represent the likely range of individual FRIs expected for a fire regime defined by the estimated FRP.

\section{Results and discussion}

\subsection{Chronologies}

The age-depth models of our four sediment records were based on a total of $56{ }^{210} \mathrm{~Pb}$-estimated ages, 41 calibrated ${ }^{14} \mathrm{C}$ ages, and one tephra-based age (Fig. 2; Table S1). The chronology for Upper Capsule Lake follows Oswald et al. (2003). The ${ }^{14} \mathrm{C}$ ages for the other three lakes are all in chronological order with the exception of the age at $107 \mathrm{~cm}$ in the Keche Lake core. This age was excluded from chronological modeling as it was considered too old based on surrounding dates; the dated material likely had resided in watershed soils before deposition in the lake, a common ${ }^{14} \mathrm{C}$ dating problem for arcto-boreal sediments (Oswald et al., 2005). The density of ${ }^{14} \mathrm{C}$ dates varies across the four sites; for example, the Tungak Lake chronology is constrained by only five ${ }^{14} \mathrm{C}$ ages for the past 35500 years, whereas the Perch Lake chronology is constrained by $10{ }^{14} \mathrm{C}$ ages for the past 9500 years.

Sedimentation rates are relatively low across all four sites. Based on the age-depth model, the Perch Lake record spans the past ca. 9500 years, with an average sedimentation rate ( \pm standard deviation) of $0.04 \pm 0.08 \mathrm{~cm} \mathrm{yr}^{-1}$ (Table 1). The Upper Capsule record spans the past ca. 12100 years, with an average sedimentation rate of $0.03 \pm 0.01 \mathrm{~cm} \mathrm{yr}^{-1}$. The Keche Lake sediment core has a modeled basal age of $11.5 \mathrm{kcal} \mathrm{BP}$ and an average sedimentation rate of $0.03 \pm 0.03 \mathrm{~cm} \mathrm{yr}^{-1}$. Tungak Lake has the oldest sediment sequence in this study, spanning the past ca. 35500 years. The sedimentation rate changes at $38 \mathrm{~cm}$ from $0.03 \pm 0.04 \mathrm{~cm} \mathrm{yr}^{-1}$ between 12.0 and $35.5 \mathrm{kcal} \mathrm{BP}$ to $0.01 \pm 0.03 \mathrm{~cm} \mathrm{yr}^{-1}$ after $12.0 \mathrm{kcal}$ BP. These relatively low sedimentation rates did not present a problem for the identification of local fires because of the rarity of fires across all four sites (see below).

\subsection{Spatial and temporal patterns of fire occurrence}

The two charcoal records from the North Slope both exhibit low background CHAR (mean is 0.008 pieces $\mathrm{cm}^{-2} \mathrm{yr}^{-1}$ for Perch and Upper Capsule) (Fig. 3b), suggesting minimal biomass burned in the region over the past ca. 12000 years. For comparison, background CHAR values have means of 0.340 pieces $\mathrm{cm}^{-2} \mathrm{yr}^{-1}$ in boreal fire records from interior Alaska (Kelly et al., 2013) and 0.012 pieces $\mathrm{cm}^{-2} \mathrm{yr}^{-1}$ in the tundra-fire records of the Noatak River Watershed (Higuera et al., 2011). Charcoal peak analysis identified only three local fires in the Perch Lake record, at $9.4 \mathrm{kcal} \mathrm{BP}, 6.5 \mathrm{kcal}$ BP, and CE 2007 (Fig. 3c). This result confirms the published finding from this site that the ARF in CE 2007 was unprecedented in the past 5000 years (Hu et al., 2010), and ex- 


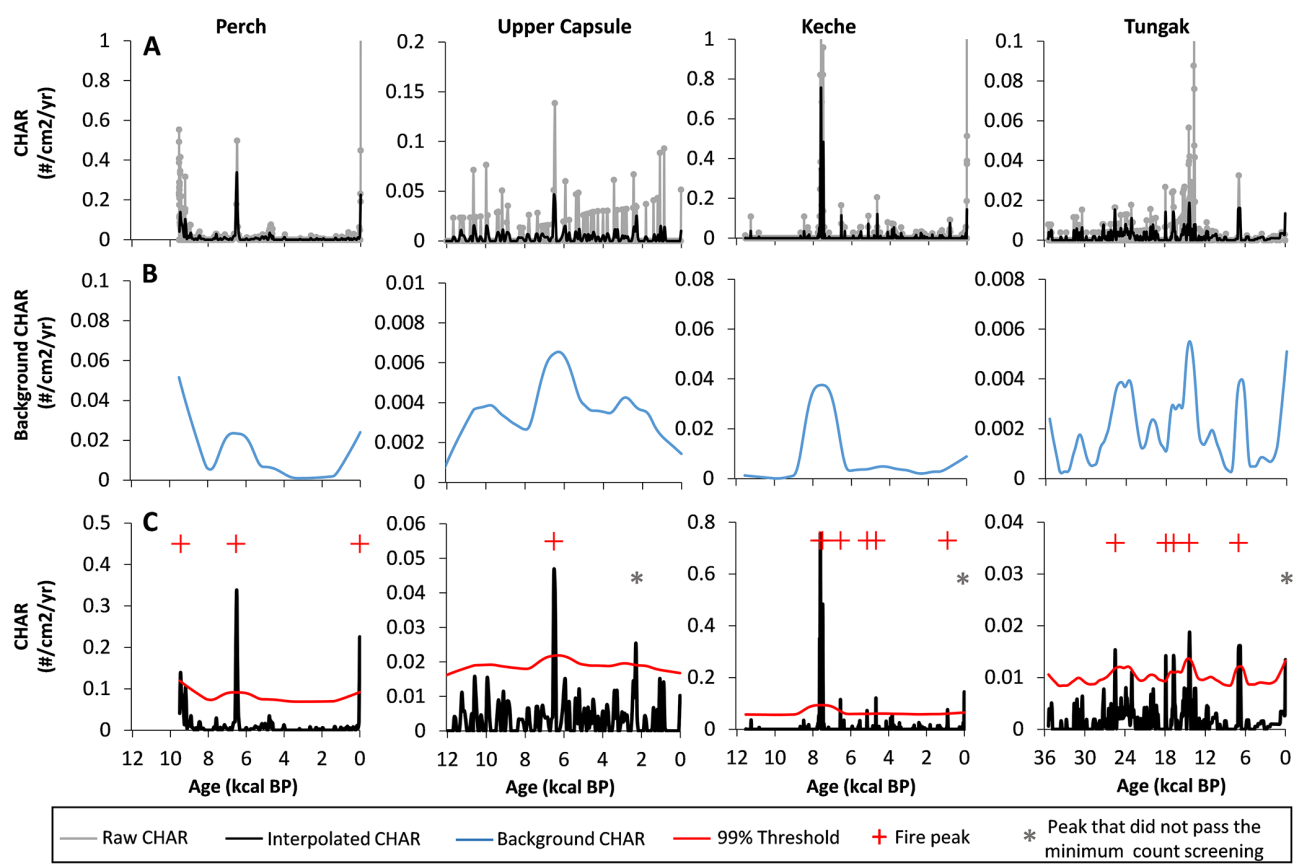

Figure 3. Charcoal records and peak analysis; panel (a) shows raw and interpolated charcoal accumulation rates, panel (b) shows background (i.e., low-frequency variability) charcoal accumulation rates and panel (c) shows charcoal peak identification.

tends the uniqueness of this fire event to the past 6500 years. Around Upper Capsule Lake, only one fire occurred during the past ca. 12000 years. This fire is dated at ca. $6.45 \mathrm{kcal} \mathrm{BP}$ (Fig. 3c), coincident with the Perch Lake fire at ca. $6.48 \mathrm{kcal}$ BP. Given the local origin of macroscopic charcoal peaks $(0.5-1.0 \mathrm{~km}$; Higuera et al., 2007) and the distance between the two lakes $(\sim 50 \mathrm{~km})$, it is unlikely that a fire event at one site resulted in a charcoal peak at the other site. Instead, the presence of a prominent charcoal peak at $6.5 \mathrm{kcal} \mathrm{BP}$ in both records likely represents a single large fire that burned across both sites. Because the magnitude of charcoal peaks reflects, in part, the amount of burned biomass (e.g., Whitlock et al., 2006; Higuera et al., 2009), the higher CHAR peak at $6.5 \mathrm{kcal}$ $\mathrm{BP}$ at Perch Lake suggests that the amount of biomass consumed in the fire at $6.5 \mathrm{kcal} \mathrm{BP}$ was greater than that of the ARF. Alternatively, two separate but similarly-timed events may have occurred in the watersheds of these lakes. Because vegetation has changed little over the past ca. 7000 years (Oswald et al., 2003), this fire event suggests that climate and/or ignition constraints on burning were relaxed during this time, perhaps as least as warm and dry as the anomalous climatic conditions that facilitated the ARF ( $\mathrm{Hu}$ et al., 2010). However, we cannot verify this interpretation because no suitable paleoclimate record with seasonal resolution is available from the region (Oswald et al., 2014).

The Keche Lake record spans several millennia during the early Holocene when tundra vegetation dominated the regional landscape and climate was generally cooler and drier than modern (Anderson and Brubaker, 1994; Kaufman et al., 2015; Clegg et al., 2011). Background CHAR is exceptionally low, with a mean of 0.0007 pieces $\mathrm{cm}^{-2} \mathrm{yr}^{-1}$ from 11.4 to $8.8 \mathrm{kcal} \mathrm{BP}$ (Fig. 3b), suggesting little burning on the early-Holocene landscape of the region. No local fires occurred around Keche Lake during this period. Background CHAR increases to a mean of 0.02 pieces $\mathrm{cm}^{-2} \mathrm{yr}^{-1}$ between 8.8 and $4.5 \mathrm{kcal}$ BP (Fig. 3b), suggesting an increase in regional burning coincident with the development of a foresttundra ecotone in the Alaskan interior with sparse stands of Picea glauca (white spruce) near Keche Lake by ca. $9.0 \mathrm{kcal}$ BP (Anderson and Brubaker, 1994). Local fires were more frequent at Keche Lake between 8.8 and $4.5 \mathrm{kcal}$ BP than during the early and late Holocene, with five events at 7.6, 7.4, 6.5, 5.1, and 4.6 kcal BP (Fig. 3c). This change implies that tundra burning was limited either by cooler summer temperatures in the early Holocene or by a lack of biomass, given that the early Holocene was drier than the middle Holocene in the Alaskan interior (Kaufman et al., 2015), which should have favored burning. It is possible that the lack of fire in the early Holocene resulted from locally moist conditions in summer, as suggested by peatland expansion that began ca. 11.2$10.7 \mathrm{kcal} \mathrm{BP}$ at a site $\sim 20 \mathrm{~km}$ to the northwest of Keche Lake (Jones and Yu, 2010). Background CHAR decreases to 0.004 pieces $\mathrm{cm}^{-2} \mathrm{yr}^{-1}$ from $4.5 \mathrm{kcal} \mathrm{BP}$ to present, and only one fire event occurred during the past ca. 4500 years near Keche Lake (Fig. 3). In contrast, area burned and fire frequency increased after $4.0 \mathrm{kcal} \mathrm{BP}$ in the boreal forests of interior Alaska (Higuera et al., 2009; Hu et al., 2006; Kelly et al., 2013). This contrast can be attributed to the develop- 
ment of flammable forests dominated by $P$. mariana (black spruce) in the lowlands of interior Alaska (Higuera et al., 2009; Kelly et al., 2013), and the absence of this species in upland treeline areas around Keche Lake. The low fire frequency at Keche Lake after $4.5 \mathrm{kcal}$ BP may have resulted from decreasing summer temperatures associated with lateHolocene neo-glaciation (e.g., Barclay et al., 2009; Clegg et al., 2011; Badding et al., 2013).

The Tungak Lake record is the longest fire-history reconstruction from Alaska. Throughout the past ca. 35000 years, low background CHAR in this record (mean is 0.002 pieces $\mathrm{cm}^{-2} \mathrm{yr}^{-1}$; Fig. 3b) suggests little burning, likely resulting from a combination of cold and sometimes arid conditions that limited biomass in the widespread graminoid-herb tundra of the region (Ager et al., 2003; Kurek et al., 2009). Only five local fires are identified over the past 35000 years (Fig. 3c). Between 25.5 and $14.0 \mathrm{kcal} \mathrm{BP}$, background CHAR is generally higher than the remainder of the record, and peak analysis shows four local fire events at 25.4, 17.8, 16.7, and $14.4 \mathrm{kcal}$ BP. During this period, the modern-day coastal regions of Alaska experienced greater continentality because of lower sea levels, resulting in more arid conditions than today (e.g., Alfimov and Berman, 2001; Kurek et al., 2009). Such conditions may have relaxed the climatic constraints on tundra burning, leading to more frequent fire events between 25.5 and $14.0 \mathrm{kcal}$ BP compared to the Holocene (i.e., after $11.7 \mathrm{kcal} \mathrm{BP})$. During the Holocene, background CHAR is lower than during the glacial period, and peak analysis suggests only one fire event, at $7.0 \mathrm{kcal}$ BP. Thus fire activity decreased during the Holocene, probably as a result of increased effective moisture in the region despite increased tundra biomass compared to the glacial period (Ager, 2003; Hu et al., 1995).

Overall, the most striking feature of our records is that these tundra regions have generally persisted as rare-fire systems for many millennia. With the exception of the ARF on the North Slope, the most recent fire events at these sites occurred from 882 to 7031 years ago (Table 2; Fig. 3c). These results stand in stark contrast with the paleofire data from the tundra ecosystems of the Noatak River Watershed. In that area, mean FRIs ranged from 135 to 309 years based on charcoal records of the past 2000 years from several lakes, comparable to mean FRIs from modern boreal forests in Alaska (Higuera et al., 2011). In northcentral Alaska, Higuera et al. (2008) documented frequent tundra fires during the lateglacial and early-Holocene period between 14 and $10 \mathrm{kcal}$ $\mathrm{BP}$, a finding supported by a microscopic charcoal record from central Alaska (Tinner et al., 2006). However, evaluating the spatial extent of this finding has not been possible because of the general lack of paleofire data from this period. Three of our four charcoal records span the entirety (Tungak Lake) or a portion of this period (Upper Capsule and Keche lakes). These new records show no enhanced fire activity during this period; only one local fire occurred near this

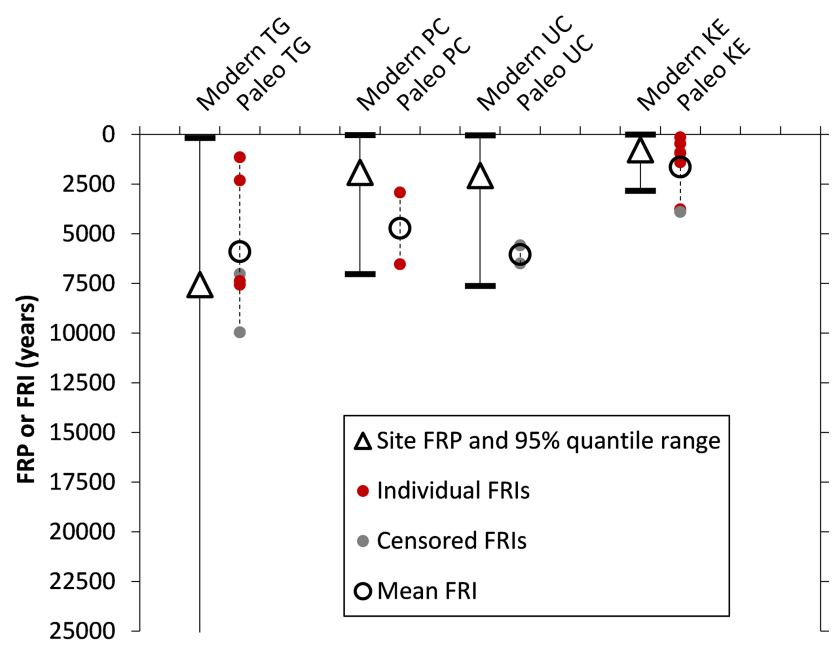

Figure 4. Fire rotation period (FRP) estimated for the $100 \mathrm{~km}$ buffer around each site, and individual and mean paleo-based fire-return intervals (FRIs) from the sediment charcoal records. $95 \%$ quantile ranges represent expected values for individual FRIs, based on the estimated FRP. Censored FRIs are individual FRIs with no modern or previous fire to constrain the interval.

time period (at $14.4 \mathrm{kcal} \mathrm{BP}$ at Tungak Lake), and regional biomass burning was consistently low across all three sites between 14 and $10 \mathrm{kcal}$ BP (Fig. 3). Together with the previous fire-history reconstructions, our data suggest that the rate of tundra burning was spatially variable throughout the late Quaternary.

\subsection{Recent tundra burning in the context of paleofire records}

Our paleofire records can provide a context for comparison with modern tundra-fire regimes by invoking the statistical equivalency of the mean FRI and the modern fire rotation period (FRP; Johnson and Gutsell, 1994). We compared our paleo-based mean FRI estimates with the FRP values calculated from spatially explicit data of modern fire observations spanning the past 63 years. Across our four sites, modern FRPs within $100 \mathrm{~km}$ of each lake ranged from 771 years (Keche Lake) to 7560 years (Tungak Lake), with intermediate values at Perch (1909 years) and Upper Capsule (2070 years) lakes (Table 2). Although the rarity of tundra burning makes these estimates highly uncertain, the spatial patterns are similar to those in our paleofire records, suggesting that the differences in tundra burning across our study sites have been present over long timescales (Fig. 4). These variations are largely related to spatial heterogeneity in climate (Young et al., 2013), consistent with the finding that summer temperature and precipitation explained $95 \%$ of the interannual variability in area burned in Alaskan tundra $(\mathrm{Hu}$ et al., 2010). 


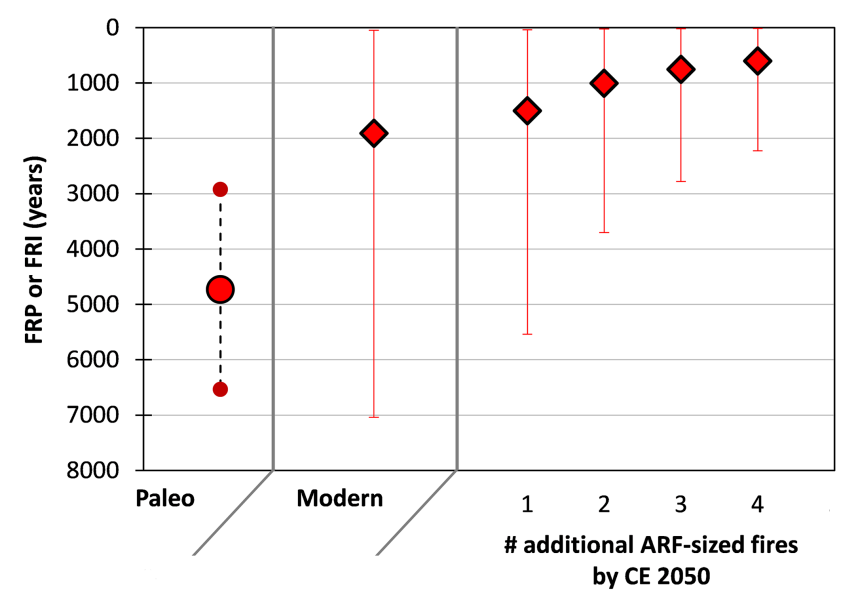

Figure 5. Perch Lake fire-return intervals (FRIs) based on paleorecords, modern fire rotation period (FRP), and FRPs for CE 2050, assuming one to four additional large fires within the $100 \mathrm{~km}$ radius around the lake. ARF-sized fires are $919.7 \mathrm{~km}^{2}$, which is the total vegetated area burned during the Anaktuvuk River Fire in a $100 \mathrm{~km}$ radius around Perch Lake. Mean and individual FRIs from Perch Lake are shown on the far left (symbols same as Fig. 4). FRP estimates are shown with $95 \%$ quantile range of expected FRIs, assuming an exponential distribution with the mean equal to the FRP.

Our paleofire analyses underestimate the true mean FRI because the oldest and most recent fire events in each record only provide minimum FRI estimates (i.e., censored intervals; Fig. 4). Despite this underestimation, at three of our four study sites, the mean FRI estimates from the paleofire records are longer than the FRP estimates based on recent fires. Specifically, the mean FRI (range) estimates of 4730 (29246536) years at Perch Lake and 6045 (> 5590 to > 6500) years at Upper Capsule Lake are much longer than the FRP $(95 \%$ quantile range) estimates of 1909 (48-7042) and 2070 (527636) years for these lakes, respectively (Fig. 4; Table 2). Likewise, the mean FRI estimate of 1648 (144-3906) years at Keche Lake is longer than the modern FRP estimate of 771 (19-2844) years. The exception is Tungak Lake where the mean FRI of 5904 (1157 to > 9968) is shorter than the FRP of 7560 (191-27 888) years. This shorter mean FRI reflects more frequent burning between 25.5 and $14.0 \mathrm{kcal} \mathrm{BP}$, when the region was probably more arid than during the Holocene. The FRP of 7560 years is similar to the most recent individual FRI of $>7031$ years at that site (Table 2). Thus our analysis suggests that the frequency of tundra burning was higher over the past 63 years at three of our four sites compared to the late Quaternary. This inference suggests elevated fire activity in some tundra regions at present, possibly as a result of anthropogenic climate change.

However, the above comparison is inconclusive, because the range of individual FRIs at each site generally falls within the broad range of FRIs that can be expected to arise by chance, as defined by the $95 \%$ quantile range around the
FRP estimates (Fig. 4). Furthermore, the ranges of individual FRIs from the paleorecords are likely influenced by past climate and vegetation conditions that differed from modern conditions, and the estimates of both mean FRI and FRP are uncertain due to the rarity of tundra fires and thus high sensitivity to individual fire events. For example, without the ARF, the FRP in the tundra region of Perch and Upper Capsule lakes would be $>100000$ years, which is much longer than the FRP estimates of Perch (1909 years) and Upper Capsule (2070 years) lakes with the inclusion of the ARF. Thus quantitative comparisons between the mean FRI estimated from our paleorecords and the FRP estimates from historic observational records inherently contain a large amount of uncertainty.

Paleorecords provide critical information regarding natural variability and thus play an important role in assessing potential anthropogenic changes in climate and ecosystems. Our results comparing paleo-inferred mean FRI and observed modern FRP illustrate an important limitation of using paleofire records in systems that rarely burn to quantitatively assess whether recent burning is beyond the range of natural variability. This limitation is applicable to other situations where the events of interest have rarely occurred in the past. One way to circumvent this limitation is to increase the spatial density of paleorecords and pool the data of detected past events to improve statistical power (Whitlock et al., 2010). Several paleofire studies have demonstrated the value of increasing the spatial density of sampling for bolstering the confidence in inferences about recent changes (Marlon et al., 2012; Kelly et al., 2013).

The utility of paleorecords with rare events may improve if the frequency of such events increases markedly in the future. To examine how much burning would be required to shift the fire regime unequivocally beyond the range of past FRIs, we considered hypothetical scenarios of future burning around Perch Lake, which has two well-constrained (i.e., uncensored) FRIs in the Holocene paleofire record. We calculated the FRP for CE 2050, assuming the addition of one to four fires of the ARF size $\left(\sim 1000 \mathrm{~km}^{2}\right)$ within the $100 \mathrm{~km}$ radius around Perch Lake (Fig. 5). One additional ARF-sized fire would shift the Perch Lake FRP estimate to 1502 years. This FRP is much shorter than the mean FRI of 4730 years based on the paleofire record from Perch Lake, and the most recent FRI at the lake (6536 years) is well outside the $95 \%$ quantile range indicated by this updated FRP estimate. Thus, the addition of a single ARF-sized fire within the $100 \mathrm{~km}$ region surrounding Perch Lake would offer compelling evidence that the modern fire regime represents a significant increase in fire activity. The occurrence of additional large fire events would further decrease the FRP and strengthen confidence in that estimate, making it increasingly difficult to accept the null hypothesis that the modern fire regime is consistent with past variability. Thus, although the rarity of fire events makes it uncertain as to whether modern fire regimes differ from the past, the uncertainty will be reduced as the ob- 
servational record grows, especially if a dramatic fire-regime shift is indeed underway. Increasing the spatial density of paleorecords to refine our understanding of past variability would enhance the rigor of testing whether or not recent and future changes in fire regimes are truly unprecedented.

\section{The Supplement related to this article is available online at doi:10.5194/bg-12-4017-2015-supplement.}

Author contributions. F. S. Hu and P. E. Higuera designed the project and led the fieldwork. M. L. Chipman and V. Hudspith performed lab work and analyses. P. E. Higuera, R. Kelly, and P. A. Duffy assisted with statistical analyses. W. W. Oswald contributed sediments and chronological data from Upper Capsule Lake. M. L. Chipman and F. S. Hu wrote the manuscript with comments from all authors.

Acknowledgements. We thank T. Brown for radiocarbon analysis and R. Vachula, C. Stephens, and M. Leonawicz for laboratory and GIS assistance. Funding for this research was provided by NSF grants ARC-1023477 to F. S. Hu and ARC-1023669 to P. E. Higuera and P. A. Duffy, and the EPA STAR Fellowship to M. L. Chipman. This manuscript benefited from discussion with D. Devotta, M. Urban, M. Fernandez, and J. Napier. The data set reported here is available at http://www.ncdc.noaa.gov/paleo/data.html.

Edited by: A. Ito

\section{References}

Ager, T. A.: Late Quaternary vegetation and climate history of the central Bering land bridge from St. Michael Island, western Alaska, Quaternary Res., 60, 19-32, 2003.

AICC - Alaska Interagency Coordination Center: Fire perimeter data, http://fire.ak.blm.gov/ (last access: 21 May 2013), 19432013.

Alfimov, A. V. and Berman, D. I.: Beringian climate during the Late Pleistocene and Holocene, Quaternary Sci. Rev., 20, 127-134, 2001.

Anderson, P. M. and Brubaker, L. B.: Vegetation history of northcentral Alaska: A mapped summary of late Quaternary pollen data, Quaternary Sci. Rev., 13, 71-92, 1994.

Badding, M. E., Briner, J. P., and Kaufman, D. S.: ${ }^{10}$ Be ages of late Pleistocene deglaciation and Neoglaciation in the north central Brooks Range, Arctic Alaska, J. Quaternary Sci., 21, 95-102, 2013.

Baker, W. L.: Fire Ecology in Rocky Mountain Landscapes, Island Press, Washington, DC, 2009.

Barclay, D. J., Wiles, G. C., and Calkin, P. E.: Holocene glacier fluctuations in Alaska, Quaternary Sci. Rev., 28, 2034-2048, 2009.

Begét, J., Mason, O., and Anderson, P.: Age, extent and climatic significance of the ca. 3400 BP Aniakchak tephra, western Alaska, USA, Holocene, 2, 51-56, 1992.
Binford, M. W.: Calculation and uncertainty analysis of $210 \mathrm{~Pb}$ dates for PIRLA project lake sediment cores, J. Paleolimnol., 3, 253 267, 1990.

CAVM Team: Circumpolar Arctic Vegetation Map. (1:7,500,000 scale), Conservation of Arctic Flora and Fauna (CAFF) Map No. 1. U.S. Fish and Wildlife Service, Anchorage, Alaska, ISBN: 09767525-0-6, ISBN-13: 978-0-9767525-0-9, 2003.

CharAnalysis v1.1 program, http://code.google.com/p/ charanalysis/, last access: 13 May 2013.

Clegg, B. F., Kelly, R., Clarke, G. H., Walker, I. R., and Hu, F. S.: Nonlinear response of summer temperature to Holocene insolation forcing in Alaska, P. Natl. Acad. Sci. USA, 108, 1929919304, 2011.

Cleveland, W. S.: Robust locally weighted regression and smoothing scatterplots, J. Am. Stat. Assoc., 74, 829-836, doi: $10.2307 / 2286407,1979$.

Eakins, J. D. and Morrison, T.: A new procedure for the determination of lead-210 in lake and marine sediments, Int. J. Appl Radiat. Is., 29, 531-536, 1978.

Gavin, D. G., Brubaker, L. B., and Lertzman, K. P.: An 1800-year record of the spatial and temporal distribution of fire from the west coast of Vancouver Island, Canada, Can. J. Forest Res., 33, 573-586, doi:10.1139/X02-196, 2003.

Gavin, D. G., Hu, F. S., Lertzman, K., and Corbett, P.: Weak climatic control of stand-scale fire history during the late Holocene, Ecology, 87, 1722-1732, 2006.

Grosse, G., Harden, J., Turetsky, M., McGuire, A. D., Camill, P., Tarnocai, C., Frolking, S., Schuur, E. A. G., Jorgenson, T., Marchenko, S., Romanovsky, V., Wickland, K. P., French, N., Waldrop, M., Bourgeau-Chavez, L., and Striegl, R. G.: Vulnerability of high latitude soil organic carbon in North America to disturbance, J. Geophys. Res., 116, G00K06, doi:10.1029/2010JG001507, 2011.

Higuera, P. E., Peters, M. E., Brubaker, L. B., and Gavin, D. G.: Understanding the origin and analysis of sediment-charcoal records with a simulation model, Quaternary Sci. Rev., 26, 1790-1809, 2007.

Higuera, P. E., Brubaker, L. B., Anderson, P. M., Brown, T. A., Kennedy, A. T., and Hu, F. S.: Frequent fires in ancient shrub tundra: Implications of paleorecords for Arctic environmental change, PLoS One, 3, e0001744, doi:10.1371/journal.pone.0001744, 2008.

Higuera, P. E., Brubaker, L. B., Anderson, P. M., Hu, F. S., and Brown, T. A.: Vegetation mediated the impacts of postglacial climate change on fire regimes in the south-central Brooks Range, Alaska, Ecol. Monogr., 79, 201-219, 2009.

Higuera, P. E., Gavin, D. G., Bartlein, P. J., and Hallett, D. J.: Peak detection in sediment-charcoal records: impacts of alternative data analysis methods on fire-history interpretations, Int. J. Wildland Fire, 19, 996-1014, 2010.

Higuera, P. E., Chipman, M. L., Barnes, J. L., Urban, M. A., and Hu, F. S.: Variability of tundra fire regimes in Arctic Alaska: millennial-scale patterns and ecological implications, Ecol. Appl., 21, 3211-3226, 2011.

Hu, F. S., Brubaker, L. B., and Anderson, P. M.: Postglacial vegetation and climate change in the northern Bristol Bay region, southwestern Alaska, Quaternary Res., 43, 382-392, 1995.

Hu, F. S., Brubaker, L. B., Gavin, D. G., Higuera, P. E., Lynch, J. A., Rupp, T. S., and Tinner, W.: How climate and vegeta- 
tion influence the fire regime of the Alaskan boreal-forest biome: the Holocene perspective, Mitig. Adapt. Strat. Gl., 11, 829-846, doi:10.1007/s11027-005-9015-4, 2006.

Hu, F. S., Higuera, P. E., Walsh, J. E., Chapman, W. L., Duffy, P. A., Brubaker, L. B., and Chipman, M. L.: Tundra burning in Alaska: Linkages to climatic change and sea ice retreat, J. Geophys. Res., 115, G04002, doi:10.1029/2009JG001270, 2010.

Kaufman, D. S., Jensen, B. J. L., Reyes, A. V., Schiff, C. J., Froese, D. G., and Pearce, N. J. G.: Late Quaternary tephrostratigraphy, Ahklun Mountains, SW Alaska, J. Quaternary Sci., 27, 344-959, 2012

Kaufman, D. S., Axford, Y. L., Henderson, A. C. G., McKay, N. P., Oswald, W. W., Saenger, C., Anderson, R. S., Bailey, H. L., Clegg, B., Gajewski, K., Hu, F. S., Jones, M. C., Massa, C., Routson, C. C., Werner, A., Wooller, M. J., and Yu, Z.: Holocene climate changes in eastern Beringia (NW North America) - A systematic review of multi-proxy evidence, Quaternary Sci. Rev., in review, 2015.

Kelly, R., Higuera, P. E., Barrett, C., and Hu, F. S.: A signal-to-noise index to quantify the potential for peak detection in sedimentcharcoal records, Quaternary Res., 75, 11-17, 2011.

Kelly, R., Chipman, M. L, Higuera, P. E, Stephanova, V., Brubaker, L., and Hu, F. S: Recent burning of boreal forests exceeds fire regime limits of the past 10,000 years, P. Natl. Acad. Sci. USA, 110, 13055-13060, doi:10.1073/pnas.1305069110, 2013.

Kurek, J., Cwyner, L. C., Ager, T. A., Abbott, M. B., and Edwards, M. E.: Late Quaternary paleoclimate of western Alaska inferred from fossil chironomids and its relation to vegetation histories, Quaternary Sci. Rev., 28, 799-811, 2009.

Johnson, E. A. and Gutsell, S. L.: Fire frequency models, methods, and interpretations, in: Advances in Ecological Research, Academic, London, England, 239-287, 1994.

Jones, B. M., Kolden, C. A., Jandt, R., Abatzoglou, J. T., Urban, F., and Arp, C. D.: Fire behavior, weather, and burn severity of the 2007 Anaktuvuk river tundra fire, North Slope, Alaska, Arct. Antarct. Alp. Res., 41, 309-316, 2009.

Jones, M. C. and Yu, Z.: Rapid deglacial and early Holocene expansion of peatlands in Alaska, P. Natl. Acad. Sci. USA, 107, 7347-7532, 2010.

Lynch, J. A., Clark, J. S., and Stocks, B. J.: Charcoal production, dispersal and deposition from the Fort Providence experimental fire: interpreting fire regimes from charcoal records in boreal forests, Can. J. Forest Res., 34, 1642-1656, doi:10.1139/X04071, 2004

Mack, M. C., Bret-Harte, M. S., Hollingsworth, T. N., Jandt, R. R., Schuur, E. A. G, Shaver, G. R., and Verbyla, D. L.: Carbon loss from an unprecedented Arctic tundra wildfire, Nature, 475, 489492, doi:10.1038/nature10283, 2011.

Marlon, J. R., Bartlein, P. J., Gavin, D. G., Long, C. J., Anderson, R. S., Briles, C. E., Brown, K. J., Colonbaroli, D., Hallett, D. J., Power, M. J., Schaar, E. A., and Walsh, M. K.: Long-term perspective on wildfires in the western USA, P. Natl. Acad. Sci. USA, 109, E535-E543, doi:10.1073/pnas.1112839109, 2012.

MCAgeDepth program, https://code.google.com/p/mcagedepth/, last access: 11 May 2009.

NALCMS - North American Land Change Monitoring System, http://www.cec.org/Page.asp?PageID=122\&ContentID=2819, last access: 22 November 2011, 2005.
NLDC - National Land Cover Database, http://www.mrlc.gov/ nlcd2006.php, last access: 13 April 2008, 2006.

Nowacki, G., Spencer, P., Fleming, M., Brock, T., and Jorgenson, T.: Ecoregions of Alaska and Neighboring Territory, U.S. Geological Survey, Reston, VA, Open-File Rep. 02-297 (map), 2001.

Oswald, W. W., Brubaker, L. B., Hu, F. S., and Kling, G. W.: Holocene pollen records from the central Arctic foothills of northern Alaska: testing the role of substrate in the response of tundra to climate change, J. Ecol., 91, 1034-1048, 2003.

Oswald, W. W., Anderson, P. M., Brown, T. A., Brubaker, L. B., Hu, F. S., Lozhikin, A. V., Tinner, W., and Kaltenrieder, P.: Effects of sample mass and macrofossil type on radiocarbon dating of arctic and boreal lake sediments, Holocene, 15, 758-767, 2005.

Oswald, W. W., Brubaker, L. B., Hu, F. S., and Kling, G. W.: LateQuaternary environmental and ecological history of the Arctic Foothills, northern Alaska, in: Alaska's Changing Arctic, Oxford University Press, New York, NY, 81-89, 2014.

PRISM Climate Group: Oregon State University, http://prism. oregonstate.edu, last access: 8 May 2012.

Reimer, P. J., Baillie, M. G. L, Bard, E., Bayliss, A., Beck, J. W., Blackwell, P. G., Bronk Ramsey, C., Buck, C. E., Burr, G. S., Edwards, R. L., Friedrich, M., Grootes, P. M., Guilderson, T. P., Hajdas, I., Heaton, T. J., Hogg, A. G., Hughen, K. A., Kaiser, K. F., Kromer, B., McCormac, G., Manning, S., Reimer, R. W., Richards, D. A., Southon, J. R., Talamo, S., Turney, C. S. M., van der Plicht, J., and Weyhenmeyer, C. E.: IntCal09 and Marine09 radiocarbon age calibration curves, 0-50,000 years cal BP, Radiocarbon, 51, 1111-1150, 2009.

Rocha, A. V. and Shaver, G. R.: Postfire energy exchange in arctic tundra: the importance and climatic implications of burn severity, Glob. Change Biol., 17, 2831-2841, 2011.

Rocha, A. V., Loranty, M. M., Higuera, P. E., Mack, M. C., Hu, F. S., Jones, B. M., Breen, A. L., Rastetter, E. B., Goetz, S. J., and Shaver, G. R.: The footprint of Alaskan tundra fires during the past half-century: implications for surface properties and radiative forcing, Environ. Res. Lett., 7, 044039, doi:10.1088/17489326/7/4/044039, 2012.

Schuur, E. A. G., Bockheim, J., Canadell, J. G., Euskirchen, E., Field, C. B., Goryachkin, S. V., Hagemann, S., Kuhry, P., Lafleur, P. M., Lee, H., Mazhitova, G., Nelson, F. E., Rinke, A., Romanovsky, V. E., Shiklomanov, N., Tarnocai, C., Venevsky, S., Vogel, J. G., and Zimov, S. A.: Vulnerability of permafrost carbon to climate change: implications for the global carbon cycle, Bioscience, 58, 701-714, 2008.

SNAP - Scenarios Network for Alaska and Arctic Planning, University of Alaska, https://www.snap.uaf.edu/tools/data-downloads, last access: 11 May 2014.

Stuiver, M. and Reimer, P.J.: Extended ${ }^{14} \mathrm{C}$ database and revised CALIB radiocarbon calibration program, Radiocarbon, 35, 215 230, 1993.

Tinner, W., Hu, F. S., Beer, R., Kaltenrieder, P., Scheurer, B., and Krähenbühl, U.: Postglacial vegetational and fire history: pollen, plant macrofossil and charcoal records from two Alaskan lakes, Veg. Hist. Archaeobot., 15, 279-293, 2006.

Walker, D. A., Raynolds, M. K., Daniëls, F. J. A., Einarsson, E., Elvebakk, A., Gould, W. A., Katenin, A. E., Kholod, S. S., Markon, C. J., Melnikov, E. S., Moskalenko, N. G., Talbot, S. S., Yurtsev, B. A., Bliss, L. C., Edlund, S. A., Zoltai, S. C., Bay, C., Wilhelm, M., Gundjónsson. G., Johansen, B. E., Ananjeva, G. V., 
Drozdov, D. S., Konchenko, L. A., Korostelev, Y. V., Polezhaev, A. N., Ponomareva, O. E., Pospelova, E. B., Safronova, I. N., Shelkunova, R. P, Fleming, M. D., and Murray, D. F.: The circumpolar Arctic vegetation map, J. Veg. Sci., 16, 267-282, 2005.

Whitlock, C., Bianchi, M. M., Bartlein, P. J., Markgraf, V., Marlon, J., Walsh, M., and McCoy, N.: Postglacial vegetation, climate, and fire history along the east side of the Andes (lat 41-42.5 degrees S), Argentina, Quaternary Res., 66, 187-201, 2006.

Whitlock, C., Higuera, P. E., McWethy, D. B., and Briles, C. E.: Paleoecological perspectives in fire ecology: Revisiting the fireregime concept, Open Ecology J., 3, 6-23, 2010.
Wright, H. E., Mann, D. H., and Glaser, P. H.: Piston cores for peat and lake sediments, Ecology, 65, 567-659, 1984.

Young, A., Higuera, P. E., Duy, P., and Hu, F. S.: Fire regime responses to climate and vegetation in Alaskan boreal-forest and tundra ecosystems: using the historic record to predict the 21st century, in: Ecological Society of America 98th Annual Meeting, Minneapolis, MN, 04-09 August 2013, COS 122-7, 2013. 